\title{
Are African Workers Getting Ahead in the New South Africa? Evidence from KwaZulu- Natal, 1993-1998
}

\author{
Paul L. Cichello \\ Cornell University \\ Gary S. Fields \\ Cornell University \\ Murray Leibbrandt \\ University of Cape Town
}

\section{Introduction ${ }^{1}$}

The problems of low labour market earnings and unemployment are at the forefront of debates about labour market policy in contemporary South Africa. High and rising unemployment rates contribute massively to poverty, but many people also earn little in the labour market because they work for few hours per week or receive low hourly wages, particularly in the informal sector. For individual South Africans, moving between the categories of unemployment, informal sector work and formal employment usually means big shifts in earnings and well-being. To understand poverty and inequality in South Africa, it is therefore crucially important to examine the patterns and dynamics of shifts (or transitions) between these categories of involvement in the labour market.

The orthodox view of contemporary labour market dynamics points to very low entrance rates into regular employment (i.e. the opportunities to move into formal sector employment are small in comparison to the number of people wanting to make this move) at the same time as there is high labour shedding of less skilled workers out of regular employment. This implies a static or even shrinking formal sector labour market that is not absorbing the increasing labour supply (Fallon and Lucas, 1998).

On the earnings side, real wages in regular employment have stayed constant or increased despite the fall in employment (ibid-, Fields, Leibbrandt and Wakeford 2000). Wage trends thus appear to be insensitive to unemployment. It has been argued that this wage rigidity is due to labour market legislation, and contributes towards the inability of the labour market to create formal sector jobs and to a lack of integration of earnings and conditions of employment between the formal and informal sectors of the economy (Nattrass, 2000a).

Most recent analyses of these employment and earnings issues have proceeded through econometric modelling using national data from surveys such as the 1993 survey conducted by the South African Labour and Development Research Unit (SALDRU) at the University of Cape Town or the 1995 October Household Survey conducted by Statistics South Africa. Data from these surveys provides 'snapshot' views of the operation of the labour market at one point in "time. Using these data, studies have revealed the importance of a range of factors including race, gender, education, and location in the determination of both employment and earnings (Hofmeyr, 2000; 
Fallon and Lucas, 1998; Bhorat and Leibbrandt, 2001; Kingdon and Knight, 2000, and in this issue). In addition to these factors, hours of work, public/private divisions, industry, occupation, union membership and racial and gender discrimination have been shown to be important determinants of earnings (Moll, 1993; Mwabu and Schultz, 1996, 1998, 2000; Jensen, 1999).

Given the static nature of these data, the authors have been appropriately reluctant to make simple extrapolations from their analyses of the labour market at one point in time to dynamic earnings and employment issues. A number of empirical studies have explicitly attempted to deal with these dynamic questions by comparing data from at least two cross-sectional surveys. These studies have shown that one can use these series of crosssections to profile accurately employment, unemployment and earnings changes at aggregate and even disaggregated levels. The analysis of aggregate, sectoral and occupational employment trends has highlighted the impacts of trade and technology in driving formal sector employment changes (Bhorat and Hodge, 1999; Edwards, 2000). The analysis of unemployment has shown that both measured unemployment rates and the profile of the unemployed are stubbornly robust across data sets and across time (Klasen and Woolard, 1999; Nattrass, 2000b). The analysis of earnings has revealed a persistence of large earnings inequalities (Moll, 2000; Bhorat, 2000), large average earnings differences by race and gender that cannot be accounted for by measurable characteristics of the earners (Moll, 2000; Allanson et al, 2000; Rospabe, 2001) and large average wage premia for unionised African workers (Rospabe, 2001; Hofmeyr and Lucas, 2000; Michaud and Vencatachellum, 2001).

This use of a series of cross-sectional surveys has added value to our understanding of the evolving nature of the labour market over the 1990s. It is worth noting that all of these studies assume that the sampling of each survey provides a reliable national picture at that time and that the sampling is comparable across surveys. This assumption is not obviously valid, and certainly warrants further interrogation.

More importantly, perhaps, there are inherent difficulties associated with using a series of cross-sections to explore labour market dynamics. If the data sets tell similar stories over time, as is the case with the unemployment studies, there is no way of knowing . whether this is because the labour market has operated in 'a stable fashion between the- surveys or whether there have been changes in earnings and employment for certain individuals and groups but these changes have netted out to very similar aggregate snapshots. Generally, repeated cross-sections cannot deal with the movement of people between labour market segments or between, jobs within sectors or with related real earnings changes over time. This is a particular concern if policy makers are really interested in knowing which specific individuals or groups are experiencing movement in the labour market and, in particular, who are the winners and losers from the current operation of the labour market.

To study these important, dynamic issues more thoroughly we need the kind of longitudinal data from panel studies that have not been available until very recently. In this paper we use the newly released panel data from the KwaZulu-Natal Income Dynamics Study (KIDS). KIDS provides data on a panel of African and Indian households in urban and rural parts of the province of KwaZulu-Natal, with surveys conducted in 1993 (as part of the countrywide SALDRU survey) and again in 1998. The panel data set, described further by May and Roberts in this issue, contains 
information on workers, their earnings, the sector of the economy in which they work, and many more features of the households in which they live. Most previous work using the KIDS data has focused on household-level issues. The only study to date that has dealt with earnings and employment mobility at the individual level is by Keswell (2000). Keswell constructs mobility matrices for terciles (i.e. thirds) and quintiles (fifths) of the earnings distribution, and estimates equations exploring the key determinants of transitions between various labour market states. A key finding of his study is that individuals and households in the bottom and top groups of the income distribution exhibit much less mobility than those in the middle.

In this paper, we use the KIDS panel data to answer three questions about the 'progress' of African workers in this one province in post-apartheid South Africa. First, how have African workers progressed as a group? Secondly, which African workers have progressed the most, and by how much have they progressed? Thirdly, to what extent is the progress made by workers driven by transitions between employment and unemployment, or between informal and formal sector employment? We reach the following major findings. First, African workers in KwaZulu-Natal had quite diverse experiences, but experienced positive progress on average. Second, those who progressed the most during the 1993 to 1998 period were individuals who started the least well off. This is a surprising conclusion given the kinds of evidence produced from cross-sectional data. Transitions between employment and unemployment and between formal and informal employment have a strong impact on real earnings, but these real earnings changes are not always as we might expect. Additionally, the sizeable changes that take place for those who do not experience such an employment transition implies that dynamics within sectors also deserve attention. A more technical analysis, complete with a variety of caveats, can be found in a Report to the Ministry of Finance (Cichello, Fields and Leibbrandt, 2001). The purpose of this article is to share these findings at a less technical level and to highlight the necessity of panel data in answering these questions.

By 'progress', we mean simply a worker's real earnings. While there are other things that are important to workers' well-being, earnings are of fundamental importance. Our analysis of earnings includes their pay in wages (or profits of the self-employed) as well as in-kind payments of food and housing. All figures for earnings in this paper are for real earnings, i.e. taking inflation into account. Growth rates refer to growth in real earnings. The term 'worker' is used loosely in this article to encompass everyone who was either employed or broadly unemployed (i.e. searching for work or discouraged from searching due to lack of jobs) in either 1993 or 1998. But we limit the analysis to individuals who were between 25 and 54 years old in 1993. This is done to prevent the analysis from being unduly influenced by earnings changes due to entrance into the workforce (among younger people) or retirement (among older people). We call this group our 'panel people'. We distinguish between 'informal' and 'formal' workers. 'Formal' is defined here as an employee who has regular hours and expects his work to continue indefinitely as well as self-employed professionals, whilst all other workers are classified as 'informal' (including the self-employed, shebeen operators, street vendors, small shop owners or taxi operators, as well as day laborers and others in casual work arrangements). Finally, our use of the word 'period' requires some clarification. Both the 1993 SALDRU and 1998 KIDS questionnaires asked questions about individuals' earnings and employment status over the immediately preceding period (of up to one 
month, depending on the question). We therefore refer to individuals' employment status (for example) in each of the 1993 and 1998 'periods'.

\section{Earnings Changes for African Workers as a Whole}

What earnings changes did workers in KwaZulu-Natal experience? Figure 1 is a histogram of earnings change experiences for Africans who worked in at least one period, i.e. it omits individuals who were unemployed in both periods. The variation in the change in earnings across individuals is quite- large. To put the magnitude of these changes in perspective, the average earnings of the available workforce was R397 per month in 1993. Yet, over 30 percent of all panel members and approximately 45 percent of those in Figure 1 experienced changes of this magnitude, either positive or negative, when we compare the 1993 and 1998 data. In contrast to these large swings in earnings is the experience of the 27 percent of all panel members not included in Figure 1 Individuals who were not working in 1993 nor in 1998 (despite desiring employment in at least one of these periods) had zero change in their earnings.

A careful look at Figure 1 also shows that the bulk of the observations lie to the right of zero and that these positive changes extend to larger gains than the losses. Indeed, 42 percent of all panel members experienced a positive change in earnings, outweighing the 31 percent who experienced declines. The average earnings change across all workers was R149, representing a 6.9 percent growth rate in earnings per year; note that this is a real increase, taking inflation into account. Thus, with more workers getting ahead than falling behind and average earnings

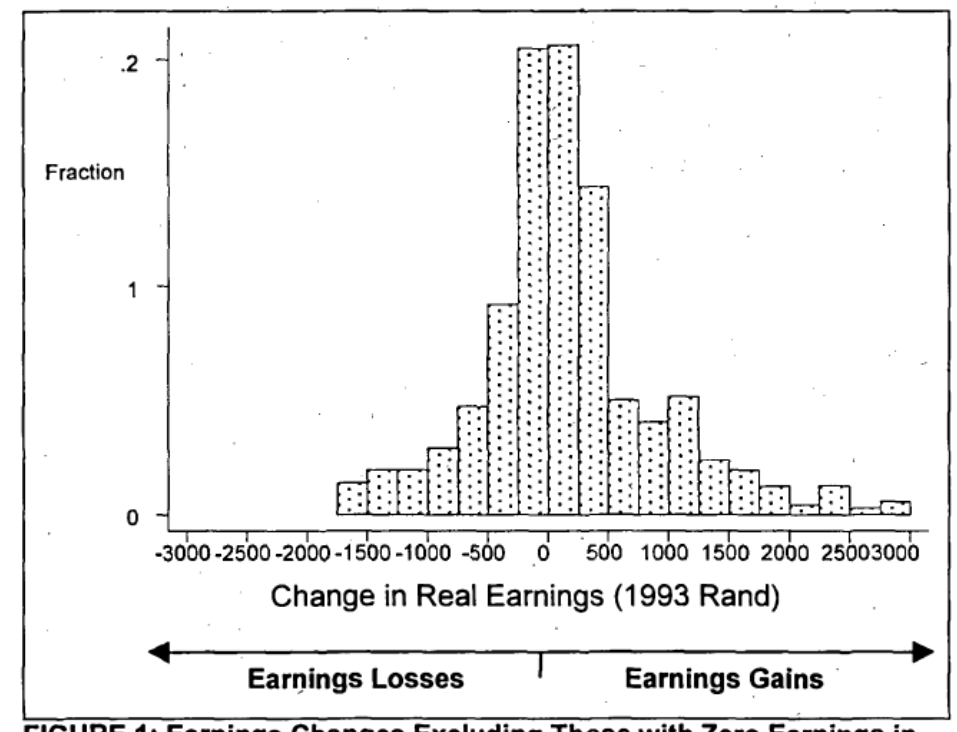

FIGURE 1: Earnings Changes Excluding Those with Zero Earnings in Both Periods, KwaZulu-Natal 1993-1998

increasing, the story for this panel of prime-aged African workers as a whole is one of improvement in the post-apartheid years. This is not to deny that there is a long way to go before incorporating all who want to work into the economy as active earners. Indeed, the significant pool of zero earners in both periods highlights this fact. ${ }^{2}$ 


\section{Who Got Ahead the Most?}

The improvement in earnings, on average, occurred in an economy that saw many losers as well as winners. This suggests that it is important to ascertain who got ahead and who fell behind. In particular, if it is the least advantaged African workers who are bearing the brunt of the downfalls while those initially well off are simply pulling further ahead, then there may be grave concern for the direction of the economy despite the gains on average.

Our analysis in these sections is governed by a number of competing hypotheses. One is the notion of 'cumulative advantage' (Merton, 1968; Boudon, 1973; Huber, 1998). This is the idea that those who start ahead get further ahead because of higher skill and ability, greater ability to save, better connections, or political influence while those who start behind get further behind owing to their lack of such advantages. It is widely thought that in today's globalized world, cumulative advantage is especially significant because the demand for skills is outpacing the available supply, bidding up the earnings of skilled workers, while at the same time, those without skills are being left out (Journal of Economic Perspectives, 1997; Friedman, 2000).

On the other hand, there are also opposing influences. One is the idea of true regression to the mean: that the earnings of those who start out temporarily ahead will tend to return to the average, while the Opposite will be the case for those who start out behind. Measurement error may provide another opposing influence. This is a statistical effect and is, therefore, more apparent than real. However, it may result in analysts misreading who it is that is getting ahead. The key idea is as follows: The dependent variable in the earnings change analysis is the difference between 1998 earnings and 1993 earnings. One of the explanatory variables is 1993 earnings. If the 1993 earnings are overstated relative to their true values for some workers, this both lowers the dependent variable and raises the independent variable, imparting a spurious negative relationship between earnings change and base earnings level. The same is true if 1993 earnings are understated for other workers. These two notions - true regression to the mean and spurious regression to the mean due to measurement error - would produce a negative relationship between earnings change and initial position.

To the extent that cumulative advantage is the dominant factor in the South African context, we would expect to find that those who got ahead the most were the most advantaged workers to begin with. On the other hand, to the extent that regression to the mean and measurement error predominate, it would be those who initially were the least advantaged who got ahead the most. 


\section{TABLE 1: Profile of Earnings Changes, by 1993 Earnings}

\begin{tabular}{|lc|}
\hline VARIABLE CATEGORY & $\begin{array}{c}\text { AVERAGE CHANGE IN } \\
\text { EARNINGS }\end{array}$ \\
TOTAL PANEL & 143.4 \\
A. BASE YEAR EARNINGS & \\
Zero earners & 302.9 \\
< 1/2 low earner line (1993R 1 to 1993R 280) & 175.5 \\
1/2 to 1 times low earner line (1993R 280-1993R 560) & 202.3 \\
1 to 2 times low earner line (1993R 560 - 1993R 1119) & 1.1 \\
$>$ 2 times low earner line (> 1993R 1119) & -385.6 \\
B. 1993 JOB CHARACTERISTICS & \\
WORK STATUS & \\
Formal Employment & \\
Informal Employment & -79.4 \\
Searching & 221.2 \\
Discouraged & 371.0 \\
Non-Available & 290.8 \\
OCCUPATIONAL GROUPING & 276.8 \\
Unskilled Occupation & \\
Semi-Skilled Occupation & 32.1 \\
Skilled Occupation & -88.8 \\
Self-Employed, Skill Unknown & -79.5 \\
INOUSTRY & 246.2 \\
Manu & \\
Agri & 2.8 \\
Commerce & -14.0 \\
Services & 193.4 \\
Other & -27.7 \\
EMPLOYER STATUS IN FORMAL SECTOR & 18.2 \\
Private Employee & \\
Public Employee & -55.1 \\
UNION STATUS IN FORMAL SECTOR & -164.9 \\
Union Member & \\
Non-Union Member & 35.2 \\
& -142.1 \\
\hline
\end{tabular}

Part A of Table 1 provides a listing of earnings changes based on the most direct indicator of initial worker well-being: their initial earnings level. For convenience, the workers are grouped into earnings categories that relate initial earnings in terms of a low earnings line. Details on the derivation of the low earnings line can be found in Bhorat and Leibbrandt (2001), but essentially the line denotes the average level of earnings a worker would need to earn in order to keep the household income above the poverty line (assuming their non-labour income and household size 
are also at an average level). The results are exceptionally clear: the initially low earners did the best. Those who started below the low earnings line experienced quite large average gains in earnings; those who started just above the low earnings line experienced essentially no change on average; and those who started at least twice the low earnings line experienced sharp declines in earnings on average.

Part B of Table 1 reports average earnings changes based on initial job characteristics. The data provide evidence that the relation between initial earnings and change in earnings is not just a statistical artefact caused by measurement error. It also paints a more detailed portrait of those who got ahead. Those in the best initial labour market positions - formal employees, those in skilled and semi-skilled occupations, and public sector employees - all had average real earnings declines, while those in the worst initial positions gained the most. The only exception is that those who were initially union members (and who earned more by virtue of that fact) seem to have done better than their non-union counterparts in the formal sector! However, these union members still have very small average gains compared to those who began in the informal sector or who started non-employed. These results stand in stark contrast to the hypothesis of cumulative advantage: excluding the union membership caveat, it was the African workers in KwaZulu-Natal who were in the least advantaged job categories, not the most advantaged, who got ahead the most between 1993 and 1998. On the whole, therefore, the univariate analysis presents a remarkably progressive picture, hitherto not known for South Africa.

\section{Cross-Section Data versus Panel Data}

In the results just presented, it is vitally important to note that progress has been measured using the second period earnings of the same individual as compared with that person's earnings in the first period, taking that person's initial job characteristic as the classifying variable. This can only be done with panel data. Had we not had a panel or had we chosen not to use the panel feature of the data, a different methodology would have been used, which is to take the average earnings of a group of people in the first period and compare them with the average earnings of people who currently share that characteristic in the second period. Thus, with panel data, we compare how a person is doing today with how that same person was doing before. With cross-sectional data, we compare how groups of people are doing compared to each other at a point in time and then compare how this changes over time. These groups could be high earners versus low earners or formal workers versus informal workers. If people did not swap positions, then these two approaches would both be addressing the same question. The key is to not be fooled into thinking that the questions are the same or that the answer to one question will be the same as the answer to the other in practice.

In the case of earnings changes in KwaZulu-Natal, the answers using these two methods prove to be strikingly different. Contrast the findings of the preceding sections to those we get if we were to take the people in our panel data set and treat them as two cross-sectional data sets. As shown in Figure 2A, the average monthly earnings among formal workers was R934 in 1993 and R1212 in 1998, a gain of R278. The average monthly earnings among informal workers was R286 
in 1993 and R550 in 1998, a gain of R264. The average earnings of unemployed workers was, of course, zero Rand in both periods, implying no gain or loss.

The cross-sectional patterns show earnings gains of similar magnitudes in the formal and the informal sectors and, of course, no earnings gain among those not employed. The analyst using only these cross-sectional data might thus be tempted to conclude that the pattern of earnings dynamics was regressive in KwaZulu-Natal.

Two more cross-sectional 'facts' only further lead us astray. First, earnings inequality among all labour force participants increased from 1993 to 1998. The Gini coefficient, which rises as inequality increases, increased from .670 to .678 . Second, among workers, the percentage of people employed in the relatively low paying informal sector increased from 34 percent to 39 percent. These 'facts' correspond to similar evidence in cross-sectional work on South African outcomes that would lead us, mistakenly, to expect that cumulative advantage has been the dominant force. Two examples are the fact that income inequality has been increasing within all racial groups (Whiteford and Van Seventer, 2000; Moll, 2000) and the fact that employment of highly-skilled workers has been increasing while that of less-skilled workers has been decreasing (Whiteford and Van Seventer, 2000; Edwards, 2000).

\section{A. Cross Section}

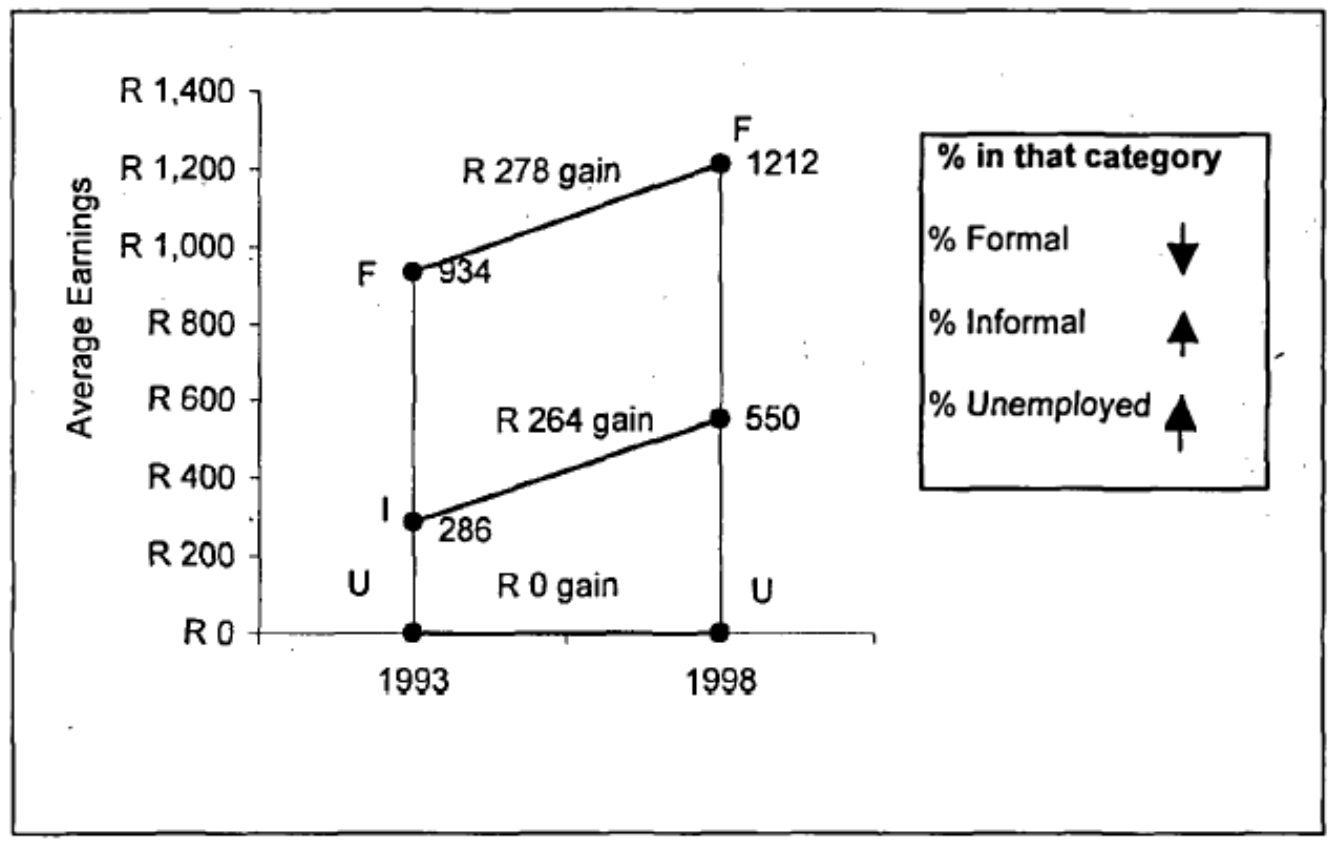




\section{B. Panel}

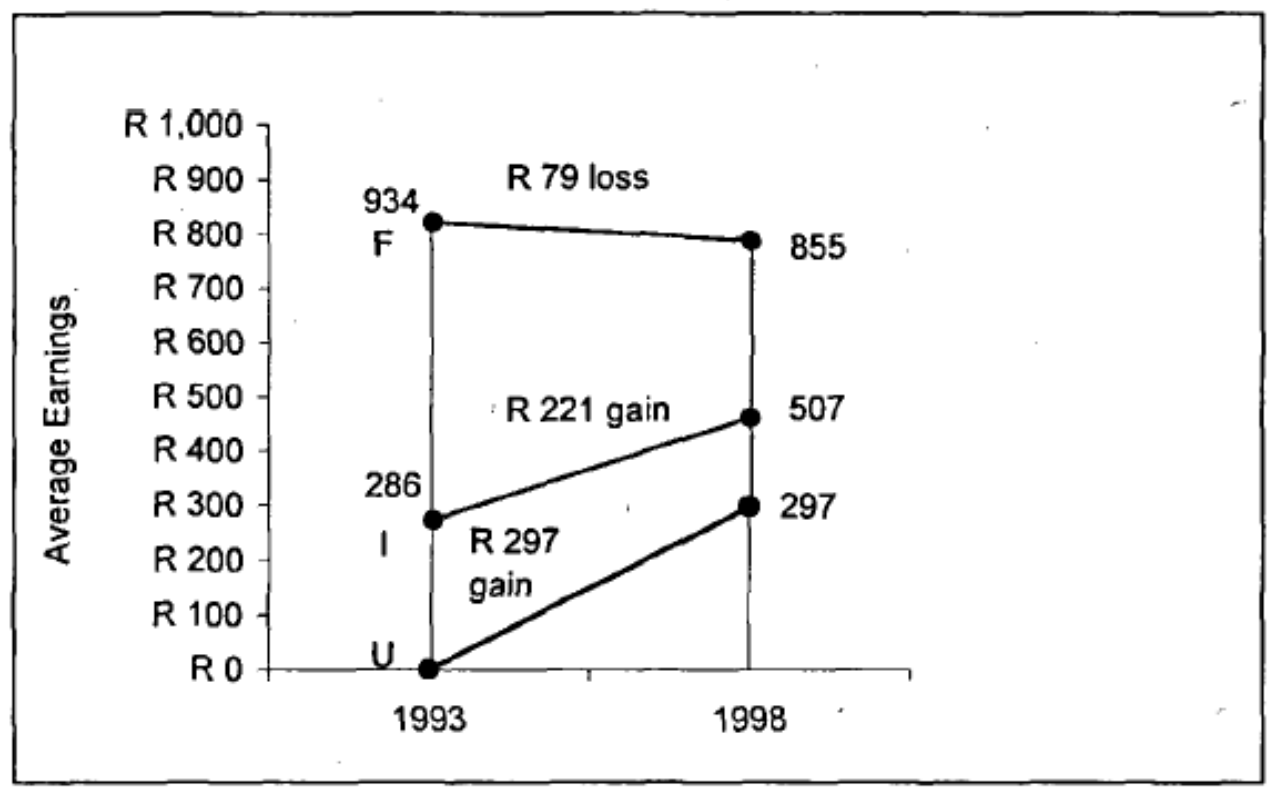

FIGURE 2: Average Earnings in 1993 and 1998

As we reported in the last section, however, the panel data shows that the change in the labour market for African people in KwaZulu-Natal has been quite progressive in nature. Those starting in the best employment positions (formal workers and workers earning more than twice the low earnings line) experienced earnings' losses on average (see Figure 2B). The panel members in formal work in 1993 had a mean earning decline of R79 per month. By contrast, those starting in the informal sector experienced sizable gains on average, with a mean gain of R221 per month. The unemployed, of course, averaged positive earnings gains, the magnitude of which was surprisingly large (at R297 per month).

In sum, our results show that cross-sectional data often cannot provide answers to the kinds of fundamentally dynamic questions that we have in mind when assessing the costs and benefits of labour market changes to workers at different positions in the income distribution. This is particularly important because many of the key labour market questions in contemporary South Africa are dynamic rather than static.

\section{Linking Employment and Earnings Changes}

Next, we seek to learn more about how employment dynamics relate to the change in earnings that African workers experienced. Table 2 is an employment transition matrix. The first row deals only with those who were formal workers in 1993. Reading across, we see that 62 percent were again engaged in formal employment in 1998, 17 percent had moved to the informal sector and 21 percent were no longer employed. The second and third rows provide similar details for those initially in the informal sector and those initially not employed, respectively. Table 2 shows that many people have moved into and out of employment and many others have moved between 
formal and informal sectors of the economy. Of the entire panel, just over half (56 percent) had the same work status in 1993 and 1998, whilst just under half (44 percent) had a different status.

\section{TABLE 2: Transition Matrix for Panel Members}

\begin{tabular}{|l|c|c|c|c|}
\hline \multirow{2}{*}{1993 Work Status } & \multicolumn{3}{|c|}{1998 Work Status } & \multirow{2}{*}{ Total } \\
\cline { 2 - 5 } & $\begin{array}{c}\text { Formal } \\
\text { Employment }\end{array}$ & Informal & $\begin{array}{c}\text { Not } \\
\text { Employed }\end{array}$ & \\
\hline Formal Employment & $62 \%$ & $17 \%$ & $21 \%$ & $100 \%$ \\
& $(243)$ & $(69)$ & $(82)$ & $(394)$ \\
\hline Informal Employment & $20 \%$ & $40 \%$ & $40 \%$ & $100 \%$ \\
& $(41)$ & $(80)$ & $(81)$ & $(202)$ \\
\hline Not Employed & $21 \%$ & $21 \%$ & $58 \%$ & $100 \%$ \\
& $(93)$ & $(93)$ & $(260)$ & $(446)$ \\
\hline Total & $36 \%$ & $23 \%$ & $41 \%$ & $100 \%$ \\
& $(377)$ & $(242)$ & $(423)$ & $(1042)$ \\
\hline
\end{tabular}

Note: The figures in brackets indicate the number of individuals.

Given that we have data at only two points in time, there is no way to identify spells of employment or unemployment that may have occurred in the intervening years. It is clear, however, that all workers are vulnerable to future spells of non-employment. For example, more than one in five of those employed in the formal sector in 1993 were not working in 1998. If we take only those formal workers who were members of a trade union in 1993, as many as 16 percent were not working in 1998. Even among those earnings greater than twice the low earnings line in 1993, 17 percent were not working in 1998. In other words, being a union member or enjoying high earnings only reduced slightly the odds of not being employed five years later.

\section{TABLE 3: Mean Earnings Change by 1993 and 1998 Work Status}

\begin{tabular}{|l|c|c|c|c|}
\hline & $\begin{array}{c}\text { Formally } \\
\text { Employed in } \\
1998\end{array}$ & $\begin{array}{c}\text { Informally } \\
\text { Employed in } \\
1998\end{array}$ & $\begin{array}{c}\text { Not } \\
\text { Employed in } \\
1998\end{array}$ & Total \\
\hline $\begin{array}{l}\text { Formally Employed } \\
\text { in } 1993\end{array}$ & $+\mathrm{R} 188$ & $-\mathrm{R} 152$ & $-\mathrm{R} 797$ & $-\mathrm{R} 79$ \\
\hline $\begin{array}{l}\text { Informally Employed } \\
\text { in 1993 }\end{array}$ & $+\mathrm{R} 878$ & $+\mathrm{R} 314$ & $-\mathrm{R} 202$ & $+\mathrm{R} 221$ \\
\hline $\begin{array}{l}\text { Not Employed in } \\
1993\end{array}$ & $+\mathrm{R} 1214$ & $+\mathrm{R} 288$ & $\mathrm{R} 0$ & $+\mathrm{R} 297$ \\
\hline
\end{tabular}

Table 3 provides a first look at how these movements across employment sectors and into and out of employment relate to changes in earnings. The table provides the average earnings change by particular employment transition experience. For example, the average earnings change for those who were in formal employment in 1993 and were not employed in 1998 was a loss of RJ97 per 
month. The loss for those who moved from informal employment to non-employment was R202 per month. The final column gives the mean changes, as already indicated in Figure 2B.

These average earnings changes provide some useful insights and surprising information. First, as expected, the gains/losses associated with entering/exiting the formal sector are larger than the gains/losses associated with entering/exiting the informal sector. The fact that the average gains from entering are larger than the average losses from leaving is to be expected given the cross-sectional changes in earnings for each sector.

Second, the earnings changes for those who were employed in the same sector in both periods - for example, individuals who were in formal work in both periods - are positive. But, surprisingly, those who remained in the informal sector experienced considerably larger earnings changes on average than those who remained in the formal sector. This average gain of R314 per month for dual informal workers is particularly strong given the fact that the average informal worker in 1993 earned only R286 per month. This is another sign that some informal workers are engaged in business that has moved well beyond the subsistence level that people often associate with such small businesses or casual employment. Of course, the fact that 40 percent of those initially in the informal sector ended up as zero earners (see Table 2) highlights the casual and risky nature of much informal work.

\section{TABLE 4: Percent Experiencing Positive Gains in Real Monthly Earnings, KwaZulu-Natal, 1993-1998}

\begin{tabular}{|l|c|c|}
\hline & $\begin{array}{c}\text { Formally Employed in } \\
1998\end{array}$ & $\begin{array}{c}\text { Informally Employed in } \\
\mathbf{1 9 9 8}\end{array}$ \\
\hline Formally Employed in 1993 & $60 \%$ & $44 \%$ \\
\hline Informally Employed in 1993 & $90 \%$ & $66 \%$ \\
\hline
\end{tabular}

Third, the earnings changes associated with movements between formal and informal sectors do not appear to be symmetric in nature. When moving from informal to formal employment earnings increase by a huge R878 per month on average, but the average decrease in earnings from moving to the informal sector from the formal sector is just R152 per month. Table 4 further emphasizes this point, presenting the percentage of individuals in a given work experience category who have positive earnings gains between 1993 and 1998. The movement from informal to formal is again a very positive experience, with fully 90 percent of such workers experiencing earnings gains. Most of those (56- percent) who move from formal to informal employment experience earnings losses. However, the fact that so many as 44 percent of such individuals experience an increase in earnings following such a transition is contrary to the popular belief that such a $r$ change implies an automatic loss in earnings and it was certainly a surprise to us. 


\section{TABLE 5: Percentage of Positive Earnings Changes, by Employment Transition Experience, KwaZulu-Natal, 1993-1998}

\begin{tabular}{|l|c|c|}
\hline & $\begin{array}{c}\text { Formally Employed in } \\
1998\end{array}$ & $\begin{array}{c}\text { Informally Employed in } \\
1998\end{array}$ \\
\hline Formally Employed in 1993 & $32.5 \%$ & $6.7 \%$ \\
\hline Informally Employed in 1993 & $8.8 \%$ & $12.6 \%$ \\
\hline Not Employed in 1993 & $19.7 \%$ & $19.7 \%$ \\
\hline Total & $61.0 \%$ & $39.0 \%$ \\
\hline
\end{tabular}

Fourth, while moving into the formal sector implies nearly universal gains with sizable average gains, there are other means of getting ahead. Table 5 takes the block of workers experiencing positive earnings changes and divides them into percentages based on their employment transitions experiences. First, it shows that 39 percent of the people who had positive earnings gains were working in the informal sector, including a contingent of workers who were previously working in the formal sector. An additional 33 percent of positive gainers were in the formal sector in both periods, rather than having changes associated with a transition to the sector. We have already shown that those remaining in the informal sector have large average gains (over R300 per month), ruling out any notions that the formal sector was the only sector providing earnings changes large enough to change a household's level of well-being.

Overall, the data in this section provide convincing evidence against the hypothesis that the only way to get ahead in South Africa is by acquiring a formal sector job. The distribution of earnings gains breaks down this way: 39 percent of individuals who experienced income gains had no involvement with the formal sector at all, 33 percent of the gainers were formally employed in both periods, and 27 percent gained by becoming formally employed. Thus, although formal employment is an important means of upward mobility, upward mobility in the informal sector is also of considerable importance in KwaZulu-Natal.

\section{Conclusion: What Did We Learn?}

The use of panel data in KwaZulu-Natal has allowed us to answer some important questions about the progress African workers have experienced since the end of Apartheid. We have been able to highlight three key findings:

First, the Post-Apartheid era has seen significant progress for many African workers in KwaZulu-Natal. African workers were experiencing increased earnings on average and more African workers experienced real gains in earnings than experienced real losses. Second, the least well off workers progressed the most on average. Contrary to what we may have expected from cross-sectional inequality data, popular discourse on the effects of globalisation, and the theory of cumulative advantage, we have found that those workers who started in the lowest earnings positions experienced the greatest gains in earnings on average. This conclusion must be tempered by the fact that a vast segment of non-earners desire employment and cannot yet find work. While 
the time period presents progress, there is a long way to go to incorporate these African workers into the pool of earners.

Thirdly, employment transitions appear to be an extremely important ingredient in earnings changes. The differences in average earnings changes are quite sizable when comparing people by their employment transition experience. Additionally, movements into the formal and informal sectors accounted for 29 and 26 percent of the positive earnings changes, respectively. This still leaves 45 percent of such changes occurring for those who remain in the same sector, and the average gains for workers in these categories were shown to be far from zero. Employment transitions are thus a major factor determining earnings changes in KwaZulu-Natal.

In answering our main questions, we have also come up with an additional discovery for understanding progress of African workers. The informal sector has undergone a transformation that has had a powerful positive impact on workers. It has grown substantially in size and seen the average earnings of its members increase. One might be tempted to think of the informal sector as a pure subsistence sector or as a low level sector used solely as a stepping-stone to formal employment. The KIDS data suggest otherwise. While the informal sector may comprise individuals of the aforementioned types, it also appears to be increasingly incorporating a segment of higher earning individuals. A full 44 percent of those who were in the formal sector saw increases in earnings when moving to the informal sector.

Finally, from a methodological point of view, this article has demonstrated that important questions concerning earnings and employment dynamics can be addressed with panel data in a way that cross-sectional data cannot allow. Yet panel data are not without their shortcomings. In terms of the analysis we have undertaken here, the most important shortcoming is that we only observe one change over a five-year period. We cannot tell when the change took place between 1993 and 1998 or indeed if there was only one change. In other words, we have not been able to say anything about transitory versus persistent change and about earnings and employment volatility. The fact that our analysis reveals more movement in the labour market than we would have expected coming into the study certainly suggests that it would be worth exploring such issues. Qualitative analysis may help shed light on underlying processes to be explored in future quantitative work.

Additional rounds of data, additional effort and care on plans for tracking individuals, and the inclusion of questions to provide validation data are needed to allow important technical fixes to the problems of person- specific effects, attrition bias, and measurement error, all of which greatly hinder causal analysis. While discussion of such technical issues has been avoided in this review of our findings, the problems involved in the collection of panel data are not to be ignored or underestimated. In the competition for the limited financial resources to produce such survey data and time allotted for each survey to occur, researchers within and across disciplines must not neglect these technical issues. 


\section{References}

Allanson, P. Atkins, J and Hinks, T. 2001. "Did the End of Apartheid Spell the Beginning of the End for Racial Wage Discrimination in South Africa?", Paper presented at the Sixth Annual Conference of the African Econometrics Society, Pretoria.

Bhorat, H. 2000. "Wage Premia and Wage Differentials in the South African Labour Market", Paper presented at the Trade and Industry Policy Secretariat 2000 Annual Forum, 18-20 September, Muldersdrift.

Bhorat, H. and Hodge, J. 1999. "Decomposing Shifts of Labour Demand in South Africa," South African Journal of Economics, 67:3, 348-80.

Bhorat, H. and Leibbrandt, M. 2001. "Correlates of Vulnerability in the South African Labour Market".

Bhorat, H., Leibbrandt, M., Maziya, M., van der Berg, S. and Woolard, I. Fighting Poverty: Labour Markets and Inequality in South Africa. (Cape Town: UCT Press).

Boudon, R. 1973. Mathematical Structures for Social Mobility. (Amsterdam: Elsevier).

Carter, M. and May, J. 1999. "Getting Ahead or Falling Behind? The Dynamics of Poverty in PostApartheid South Africa", University of Wisconsin 'Working Paper.

Cichello, P., Fields, G. and Leibbrandt, M. 2001. "Which African Workers Have Gotten Ahead and by How Much? The Story of KwaZulu-Natal, South Africa, 1993-98”, Final Report to the Department of Finance. March.

Edwards, L. 2000. “Labour Shedding Output Growth: Is Trade the Culprit?” Trade and Industry Monitor Volume 14, June 2000.

Fallon, P. and Lucas, R. 1998. "South African Labour Markets: Adjustment and Inequalities", Discussion Paper No. 12, Informal Discussion Papers on Aspects of the Economy of South African. World Bank Southern African Department, Washington.

Fields, G., Leibbrandt, M. and Wakeford, J. 2000. "Key Labour Market Elasticities". Unpublished Report for the Department of Finance.

Friedman, T. 2000. The Lexus and the Olive Tree. (New York: Anchor Books).

Hofmeyr, J. 2000. "The Changing Patterns of Segmentation in the South African Labour Market", Studies in Economics and Econometrics, 24(3): 109-128.

Hofmeyr, J. and Lucas, R. 2000. “The Rise of Union Wage Premia in South Africa”. Mimeo, Boston University.

Huber, J. C. 1998. 'Cumulative Advantage and Success-Breeds-Success: The Value of Time Pattern Analysis", Journal of the American Society for Information Science. 49(5):471476. 
Jensen. R. 1999. “A Semi-Parametric Analysis of African-White Wages Differences in the South African Public and Private Sectors". John F Kennedy School of Government, Harvard University, processed.

Keswell, M. 2000. "Labour Market Dynamics in South Africa - Evidence from KwaZulu-Natal Province", Trade and Industry Policy Secretariat 2000 Annual Forum, 18-20 September, Muldersdrift.

Kingdon, G. and Knight, J. 2000. "'Are Searching and Non-searching Unemployment Distinct States when Unemployment is High? The Case of South Africa". Unpublished mimeo, University of Oxford.

Klasen, S. and Woolard, 1. 1998. "Levels, Trends and Consistency of Employment and Unemployment . Figures in South Africa", Development Southern Africa, 16( 1), 3-35.

Maluccio, J, Haddad, L. and May, J. 2000. "Social Capital and Income Generation in South Africa 19931998”, Centre for Social and Development Studies, Journal of Development Studies, 36(6), 54-81. '

May, J., Carter, M., Haddad, L., and Maluccio, J. 2000. KwaZulu-Natal Income Dynamics Study (KIDS) 1993-98: A Longitudinal Household Data Set for South African Policy Analysis, University of Natal, Durban, University of Wisconsin, Madison and International Food Policy Research Institute.

Merton, M. 1968. "The Matthew Effect in Science", Science, January 5.

Michaud, P and Vencatachellum, D. 2001. "Female and Male.Union Wage Premium un South Africa", Unpublished Seminar Paper, School of Economics, University of Cape Town. August.

Moll, P. 1993. "Industry Wage Differentials and Efficiency Wages”, Journal of Development Economics, 41:214-246.

Moll, P. 2000. "Discrimination is Declining in South Africa but Inequality is Not", Studies in Economics and Econometrics, 24(3):91 -108.

Mwabu, G. and Schultz. T.P. 1996. "Education Returns Across Quantiles of the Wage Function; Alternative Explanations for the Returns to Education by Race in South Africa", American Economic Review. 86(2):335-339.

Mwabu, Ci. and Schultz, T. 1998. "Labour Unions and the Distribution of Wages and Employment in South Africa'", Industrial and Labor Relations Review, 51 (4):680-703.

Mwabu, G. and Schultz, T.P. 2000. "Wage Premiums for Education and Location of South African Workers, by Gender and Race”, Economic Development and Cultural Change, 48 (2):307- 334.

Nattrass, N. 2000a. "Inequality, Unemployment and Wage-Setting Institutions in South Africa", Studies in Economics and Econometrics, 24(3): 129-142. 
Nattrass, N. 2000b. "The Debate About Unemployment in the 1990s", Studies in Economics and Econometrics, 24(3):73-89.

Rospabe, S. 2001. "How Did Labour Market Racial Discrimination Evolve After the End of Apartheid", Unpublished Seminar Paper, School of Economics, University of Cape Town. November.

"Symposium on Wage Inequality", 1997. Journal of Economic Perspectives, 11(2).

Whiteford, A. and Van Seventer, D.E. 2000. "South Africa's Changing Income Distribution in the 1990s". Studies in Economics and Econometrics, 24(3):7-30.

\section{Notes}

1. This work was supported by a grant from the U.S. Agency for International Development via Robert Nathan Associates. The authors gratefully acknowledge the contributions of these institutions.

2. Note that this finding on this panel cannot be extrapolated to the entire population, because the panel excludes young people entering and older people leaving it the labour market between the two surveys. It is possible that young people enter the labour market with lower average earnings (perhaps because of high rates of unemployment) than the retirees.

3. The highest 1 percent of positive and negative earnings changes are also excluded. 